\title{
Collagen Alpha-3(VI) Chain
}

National Cancer Institute

\section{Source}

National Cancer Institute. Collagen Alpha-3(VI) Chain. NCI Thesaurus. Code C150667.

Collagen alpha-3(VI) chain (3177 aa, $\sim 344 \mathrm{kDa}$ ) is encoded by the human COL6A3 gene.

This protein plays a role in extracellular matrix formation and cell-matrix adhesion in connective tissues. 